Prepared in cooperation with Blaine County, Idaho

Post-Fire Debris-Flow Hazard Assessment of the Area Burned by the 2013 Beaver Creek Fire near Hailey, Central Idaho

Open-File Report 2013-1273 



\section{Post-Fire Debris-Flow Hazard Assessment of the Area Burned by the 2013 Beaver Creek Fire near Hailey, Central Idaho}

By Kenneth D. Skinner

Prepared in cooperation with Blaine County, Idaho

Open-File Report 2013-1273 


\section{U.S. Department of the Interior \\ SALLY JEWELL, Secretary}

\section{U.S. Geological Survey \\ Suzette M. Kimball, Acting Director}

U.S. Geological Survey, Reston, Virginia: 2013

For more information on the USGS-the Federal source for science about the Earth,

its natural and living resources, natural hazards, and the environment-visit

http://www.usgs.gov or call 1-888-ASK-USGS

For an overview of USGS information products, including maps, imagery, and publications, visit $h$ ttp://www.usgs.gov/pubprod

To order this and other USGS information products, visit $h$ ttp://store.usgs.gov

Suggested citation:

Skinner, K.D., 2013, Post-fire debris-flow hazard assessment of the area burned by the 2013 Beaver Creek Fire near Hailey, central Idaho: U.S. Geological Survey Open-File Report 2013-1273, 12 p., 9 pls.,

http://dx.doi.org/10.3133/ofr20131273.

ISSN 2331-1258 (online)

Any use of trade, firm, or product names is for descriptive purposes only and does not imply endorsement by the U.S. Government.

Although this information product, for the most part, is in the public domain, it also may contain copyrighted materials as noted in the text. Permission to reproduce copyrighted items must be secured from the copyright owner. 


\section{Contents}

Abstract

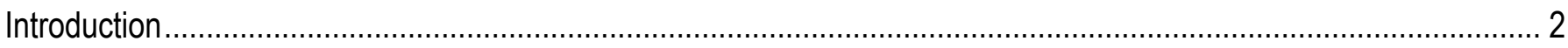

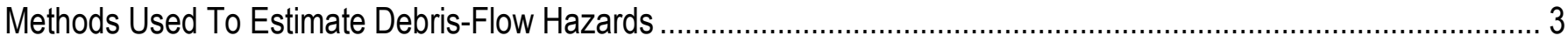

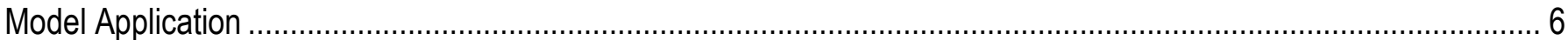

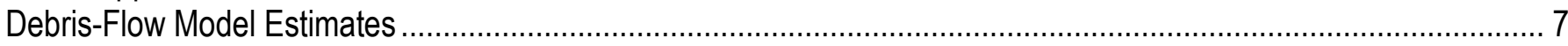

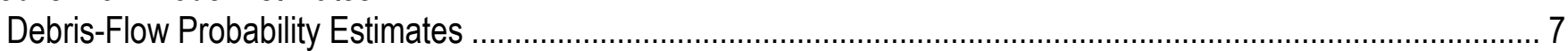

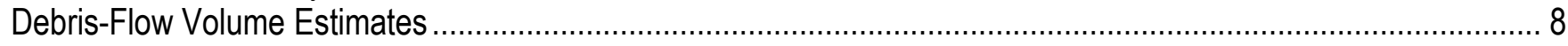

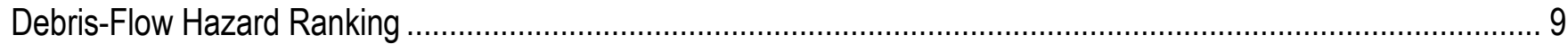

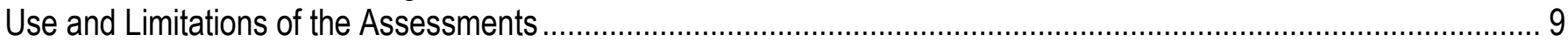

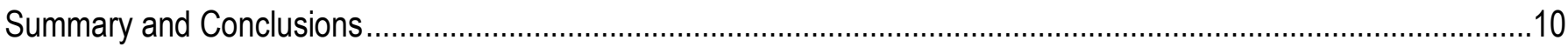

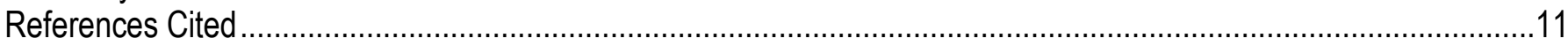

\section{Plates}

[Plates 1-9 are available for download at http://pubs.usgs.gov/of/2013/1273/.]

1. Estimated probability of occurrence for post-fire debris flows in response to a 2-year, 1-hour storm (13 mm) in the 2013 Beaver Creek Burn Area near Hailey, central Idaho.

2. Estimated volume $\left(\mathrm{m}^{3}\right)$ of post-fire debris flows in response to a 2-year, 1-hour storm (13 mm) in the 2013 Beaver Creek Burn Area near Hailey, central Idaho.

3. Estimated hazard of post-fire debris flows in response to a 2-year, 1- hour storm (13 mm) in the 2013 Beaver Creek Burn Area near Hailey, central Idaho.

4. Estimated probability of occurrence for post-fire debris flows in response to a 10-year, 1-hour storm (19 mm) in the 2013 Beaver Creek Burn Area near Hailey, central Idaho.

5. Estimated volume $\left(\mathrm{m}^{3}\right)$ of post-fire debris flows in response to a 10-year, 1-hour storm $(19 \mathrm{~mm})$ in the 2013 Beaver Creek Burn Area near Hailey, central Idaho.

6. Estimated hazard of post-fire debris flows in response to a 10-year, 1- hour storm (19 mm) in the 2013 Beaver Creek Burn Area near Hailey, central Idaho.

7. Estimated probability of occurrence for post-fire debris flows in response to a 25-year, 1-hour storm (22 mm) in the 2013 Beaver Creek Burn Area near Hailey, central Idaho.

8. Estimated volume $\left(\mathrm{m}^{3}\right)$ of post-fire debris flows in response to a 25 -year, 1-hour storm $(22 \mathrm{~mm})$ in the 2013 Beaver Creek Burn Area near Hailey, central Idaho.

9. Estimated hazard of post-fire debris flows in response to a 25-year, 1- hour storm $(22 \mathrm{~mm})$ in the 2013 Beaver Creek Burn Area near Hailey, central Idaho.

\section{Figure}

Figure 1. Burn severity of the Beaver Creek fire near Hailey, central Idaho, as established by the Burned Area Emergency Response (BAER) team, September 2013 


\section{Table}

[Table 1 is available for download at http://pubs.usgs.gov/of/2013/1273/.]

Table 1. Estimated debris-flow probability, volume, and combined hazard ranking for three storm models for the 2013 Beaver Creek fire near Hailey, central Idaho.

\section{Conversion Factors and Datum}

\section{Conversion Factors}

SI to Inch/Pound

\begin{tabular}{lcl}
\hline \multicolumn{1}{c}{ Multiply } & By & \multicolumn{1}{c}{ To obtain } \\
\hline millimeter $(\mathrm{mm})$ & Length & \\
meter $(\mathrm{m})$ & 0.03937 & inch (in.) \\
kilometer $(\mathrm{km})$ & 3.281 & foot $(\mathrm{ft})$ \\
meter $(\mathrm{m})$ & 0.6214 & mile (mi) \\
\hline & 1.094 & yard (yd) \\
\hline square meter $\left(\mathrm{m}^{2}\right)$ & Area & \\
square kilometer $\left(\mathrm{km}^{2}\right)$ & 0.0002471 & acre \\
square kilometer $\left(\mathrm{km}^{2}\right)$ & 247.1 & acre \\
\hline & 0.3861 & square mile $\left(\mathrm{mi}^{2}\right)$ \\
\hline cubic meter $\left(\mathrm{m}^{3}\right)$ & Volume & \\
cubic meter $\left(\mathrm{m}^{3}\right)$ & 35.31 & cubic foot $\left(\mathrm{ft}^{3}\right)$ \\
cubic meter $\left(\mathrm{m}^{3}\right)$ & 1.308 & cubic yard $\left(\mathrm{yd}^{3}\right)$ \\
\hline
\end{tabular}

\section{Datum}

Horizontal coordinate information is referenced to the North American Datum of 1983 (NAD 83). 


\title{
Post-Fire Debris-Flow Hazard Assessment of the Area Burned by the 2013 Beaver Creek Fire near Hailey, Central Idaho
}

\author{
By Kenneth D. Skinner
}

\begin{abstract}
A preliminary hazard assessment was developed for debris-flow hazards in the 465 squarekilometer (115,000 acres) area burned by the 2013 Beaver Creek fire near Hailey in central Idaho. The burn area covers all or part of six watersheds and selected basins draining to the Big Wood River and is at risk of substantial post-fire erosion, such as that caused by debris flows. Empirical models derived from statistical evaluation of data collected from recently burned basins throughout the Intermountain Region in Western United States were used to estimate the probability of debris-flow occurrence, potential volume of debris flows, and the combined debris-flow hazard ranking along the drainage network within the burn area and to estimate the same for analyzed drainage basins within the burn area. Input data for the empirical models included topographic parameters, soil characteristics, burn severity, and rainfall totals and intensities for a (1) 2-year-recurrence, 1-hour-duration rainfall, referred to as a 2year storm (13 mm); (2) 10-year-recurrence, 1-hour-duration rainfall, referred to as a 10-year storm (19 $\mathrm{mm}$ ); and (3) 25-year-recurrence, 1-hour-duration rainfall, referred to as a 25-year storm (22 $\mathrm{mm}$ ).

Estimated debris-flow probabilities for drainage basins upstream of 130 selected basin outlets ranged from less than 1 to 78 percent with the probabilities increasing with each increase in storm magnitude. Probabilities were high in three of the six watersheds. For the 25 -year storm, probabilities were greater than 60 percent for 11 basin outlets and ranged from 50 to 60 percent for an additional 12 basin outlets. Probability estimates for stream segments within the drainage network can vary within a basin. For the 25-year storm, probabilities for stream segments within 33 basins were higher than the basin outlet, emphasizing the importance of evaluating the drainage network as well as basin outlets. Estimated debris-flow volumes for the three modeled storms range from a minimal debris flow volume of 10 cubic meters $\left[\mathrm{m}^{3}\right]$ ) to greater than $100,000 \mathrm{~m}^{3}$. Estimated debris-flow volumes increased with basin size and distance downstream. For the 25-year storm, estimated debris-flow volumes were greater than $100,000 \mathrm{~m}^{3}$ for 4 basins and between 50,000 and 100,000 $\mathrm{m}^{3}$ for 10 basins. The debris-flow hazard rankings did not result in the highest hazard ranking of 5, indicating that none of the basins had a high probability of debris-flow occurrence and a high debris-flow volume estimate. The hazard ranking was 4 for one basin using the 10-year-recurrence storm model and for three basins using the 25-yearrecurrence storm model.
\end{abstract}

The maps presented herein may be used to prioritize areas where post-wildfire remediation efforts should take place within the 2- to 3-year period of increased erosional vulnerability. 


\section{Introduction}

The Beaver Creek fire, a lightning-caused wildfire, started in August 2013 and burned for several weeks in areas of central Idaho managed by the Sawtooth National Forest and Bureau of Land Management, as well as privately owned lands. The Beaver Creek fire covered approximately $465 \mathrm{~km}^{2}$ $(115,000$ acres) and approached the city of Hailey, Idaho (fig. 1). Burn severity was moderate to high for 57 percent of the area within the fire perimeter. The burn area is at risk for post-fire erosion, such as that caused by debris flows and flash floods, several of which have already (November 2013) occurred.

Debris flows have been documented after many wildfires in the Western United States (Cannon and others, 2007, 2010; DeGraff and others, 2011) and can threaten lives, property, infrastructure, aquatic habitats, and water supplies. Rainfall on burn areas can result in transport and deposition of large volumes of sediment, both within and downstream of burn areas. The rapid transport of large amounts of material makes debris flows particularly dangerous. In addition, debris flows following a wildfire can occur in places where flooding or sedimentation have not been observed in the past and can be generated in response to short-duration and low-recurrence-interval rainfall (Cannon and others, 2007, 2010; DeGraff and others, 2011).

The hydrologic response of drainage basins intensifies under post-fire conditions of decreased vegetation cover and altered soil properties. Wildfires can consume rainfall-intercepting canopy, litter, and duff (Moody and Martin, 2001a, 2001b; Cannon and Gartner, 2005). Water-repellent qualities in some soils can be increased or induced by the intense heat of a wildfire (DeBano, 1981; Doerr and others, 2000; Letey, 2001; Woods and others, 2006), and increased overland flow and erosion can occur as a result (Wells, 1987; Moody and Martin, 2001a, 2001b). Fine ash, which may expand when wetted, can block soil pore spaces and further reduce infiltration of water (Romkens and others, 1990; Woods and others, 2006). After a wildfire, the drainage basin response to rainfall events shifts, in general terms, from infiltration dominated to runoff dominated (Cannon and others, 2010). Because of reduced soil infiltration, rainfall on wildfire burn areas can run off almost immediately as overland flow. This runoff in low-order channels can erode surficial materials, producing a flow that is rich in ash, soil, boulders, and dislodged vegetation. As additional sediment is entrained, sediment-laden flow in channels can transition into debris flows that can negatively affect lives, property, infrastructure, aquatic habitats, and water supplies (Cannon and Gartner, 2005). Debris flows are most frequent within 2-3 years after wildfires, when vegetative cover is absent or reduced and abundant materials are available for erosion and transport (Cannon and Gartner, 2005; Cannon and others, 2010). Variability in climatic conditions following a wildfire, such as an extended period that is wetter or dryer than normal, could affect the duration of vulnerability.

This report, prepared in cooperation with Blaine County, presents a preliminary assessment of the debris-flow hazards from drainage basins burned in 2013 by the Beaver Creek wildfire near Hailey, Idaho, in the Sawtooth National Forest. This report provides estimates of the probability of debris-flow occurrence and volume of debris along the drainage network throughout the entire area, as well as estimates for drainage basins upstream of 130 selected basin outlets in response to three design storms:

1. 2-year-recurrence, 1-hour duration rainfall of 13 millimeters $(\mathrm{mm})$, referred to as a 2-year storm (a 50-percent chance of occurrence in any given year);

2. 10-year-recurrence, 1 -hour-duration rainfall of $19 \mathrm{~mm}$, referred to as a 10-year storm (a 10percent chance of occurrence in any given year); and

3. 25-year-recurrence, 1-hour-duration rainfall of $22 \mathrm{~mm}$, referred to as a 25-year storm (a 4percent chance of occurrence in any given year). 


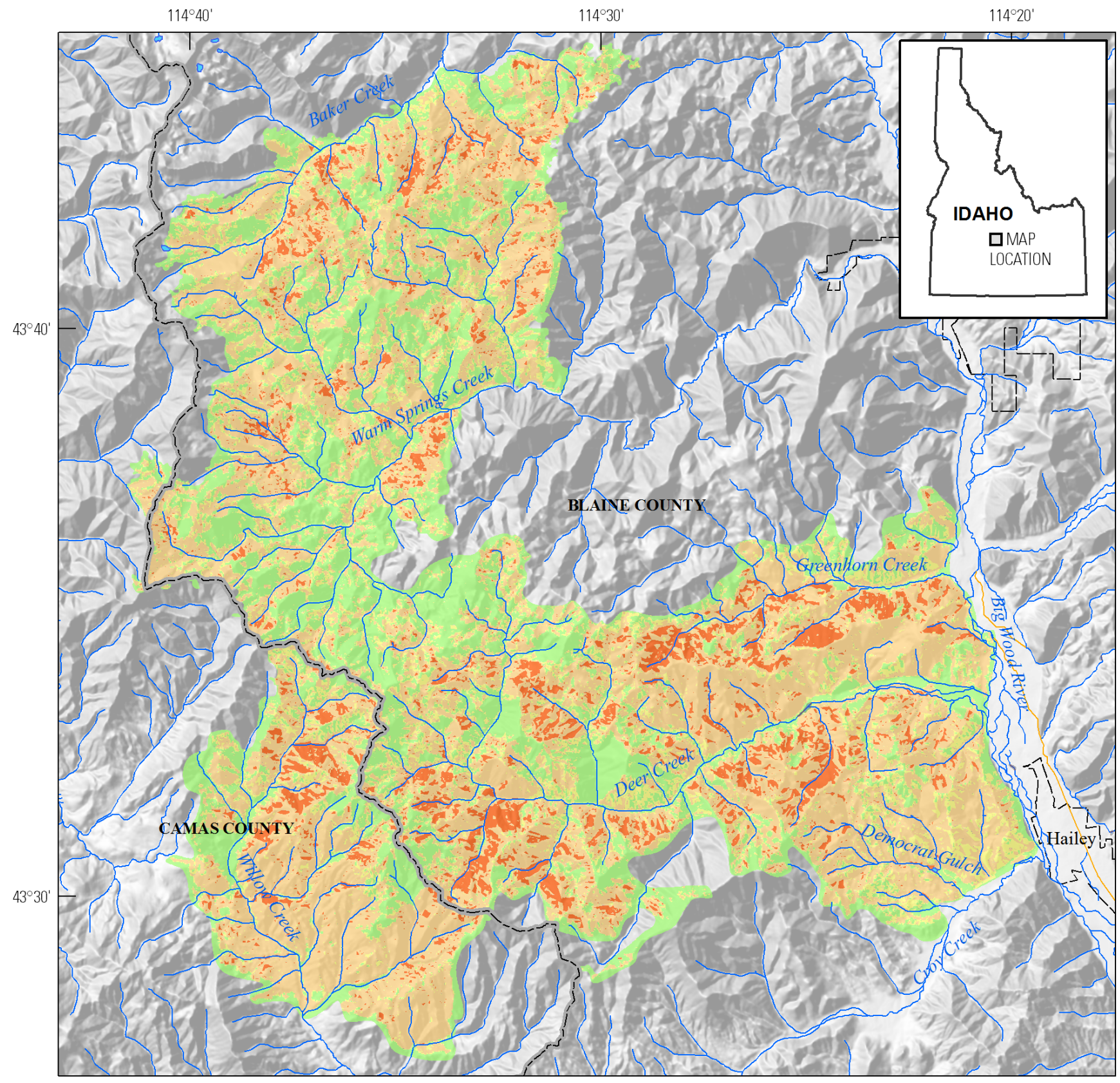

Base from U.S. Geological Survey digital data $30 \mathrm{~m}$ shaded relief, 2002, and 1:100,000 hydrography, 2007.

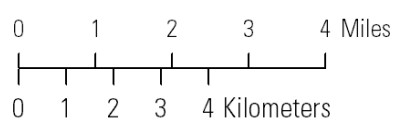

EXPLANATION

Burn Severity

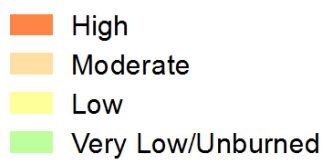

Figure 1. Burn severity of the Beaver Creek fire near Hailey, central Idaho, as established by the Burned Area Emergency Response (BAER) team, September 2013. 


\section{Methods Used To Estimate Debris-Flow Hazards}

For this hazard assessment, a set of empirical equations (models) were used to estimate the probability and volume of debris flow. The model outputs were combined to produce a relative ranking of debris-flow hazard along drainage networks and for drainage basins upstream of 130 selected basin outlets in response to three storms in the Beaver Creek Fire burn area (fig. 1). The model for estimating debris-flow probability was developed by Cannon and others (2010) by using logistic multipleregression analyses of data from 388 drainage basins in 15 burn areas in the Intermountain Western United States. Equation 1 is used to calculate debris-flow probability (Cannon and others, 2010):

$$
P=\frac{e^{x}}{1+e^{x}}
$$

where

$P \quad$ is the probability of debris-flow occurrence in fractional form, and

$e^{x} \quad$ is the exponential function where e represents the mathematical constant 2.718 .

Equation 2 is used to calculate $\mathrm{x}$ :

$$
\mathrm{x}=-0.7+0.03(\% S G 30)-1.6(R)+0.06(\% A B)+0.07(I)+0.2(\% C)-0.4(L L)
$$

where

$\%$ is the percentage of the drainage basin area with slopes equal to or greater than 30 percent;

$R \quad$ is the drainage basin ruggedness, the change in drainage basin elevation (in meters) divided by the square root of the drainage basin area (in square meters) (Melton, 1965);

$\% A B$ is the percentage of drainage basin area burned at moderate and high severities;

$I \quad$ is average storm intensity (total storm rainfall divided by the storm duration, in millimeters per hour);

$\% C \quad$ is the clay content of the soil (percent); and

$L L \quad$ is the liquid limit of the soil (percentage of soil moisture by weight at which soil changes from plastic to liquid behavior) (Das, 1983).

The second empirical model was developed by using multiple linear-regression analyses of data compiled from 56 debris-flow-producing drainage basins burned by eight fires (Cannon and others, 2010). The model provides estimates of the volume of material that may pass through a drainage-basin outlet in response to a given magnitude storm. The equation has the following form:

$$
\operatorname{Ln}(V)=7.2+0.6(\operatorname{Ln}(S G 30))+0.7(A B)^{0.5}+0.2(T)^{0.5}+0.3
$$

where

$V \quad$ is the debris-flow volume (in cubic meters);

$S G 30$ is the drainage basin area with slopes equal to or greater than 30 percent (in square kilometers);

$A B$ is the drainage basin area burned at moderate and high severities (in square kilometers);

$T \quad$ is the total storm rainfall (in millimeters); and

0.3 is a bias-correction factor that changes the predicted estimate from a median to a mean value (Helsel and Hirsch, 2002; Cannon and others, 2010). 
Values for both probability and volume were obtained along drainage networks by using the continuous parameterization technique (Verdin and Greenlee, 2003; Verdin and Worstell, 2008). With this technique, estimates of debris-flow probability and volume (Cannon and others, 2010) were obtained for every 10-m pixel along the drainage network (pls. 1, 2, 4, 5, 7, and 8) as a function of conditions in the drainage basin upstream of each pixel. This technique was developed as an alternative to basin-characterization approaches used in the past (for example, Cannon and others, 2010), which require definition of outlets and their corresponding drainage basins at the beginning of the analysis. The technique used here allows for a synoptic view of conditions throughout the study area, which can be used to identify specific 10-m pixels or stream reaches within a basin that might pose a higher risk of debris flows; the technique also aids in sampling design and monitoring-site selection.

This methodology has been used extensively for several previous post-wildfire debris-flow estimations. Several examples include the 2011 Horseshoe II Fire in Arizona (Ruddy, 2011) and two fires in 2012 - the High Park Fire in Colorado (Verdin and others, 2012) and the Little Bear Fire in New Mexico (Tillery and Matherne, 2013). Most recently, five wildfires were evaluated in 2013 including the Beaver Creek Fire in central Idaho described herein; the West Fork Complex Fire in Colorado (Verdin and others, 2013); and three fires in California - the Mountain Fire (Staley and others, 2013a), Powerhouse Fire (Staley and others, 2013b), and the Rim Fire (Staley, 2013).

The continuous-parameterization layers were built from the 1/3-arc-second National Elevation Dataset (10-m cell size) (Gesch and others, 2002; Gesch, 2007). This digital elevation model (DEM) was transformed into a projection system appropriate to the study area (Idaho Transverse Mercator) and processed by using standard DEM-conditioning tools in ArcGIS (Environmental Systems Research Institute, Inc., 2013) and RiverTools (Rivix, LLC, 2012). The DEM was used to derive the overland flow structure in the form of a flow-direction matrix in eight directions. The flow-direction matrix and a weighted flow accumulation algorithm were then used to derive values of the independent spatial variables driving the probability and volume equations for every grid cell within the extent of the DEM.

Because of orographic effects of the mountainous terrain and the size of the burn area, actual storm totals and intensities will vary in both space and time. For this study, however, the maximum rainfall of the storm was assumed to be uniform over the entire burn area, providing the most conservative estimate of the probability and volumes of potential debris flows. Values for all other independent variables driving the debris-flow probability and volume equations were obtained by using the continuous-parameterization approach. The independent-variable values can be represented as forming continuous surfaces over the burn area. Once the surfaces of the independent variables were developed, the probability and volume equations were solved by using map algebra for each grid cell along the drainage network, thus deriving the probability and volume surfaces. Along the drainage network, drainage basins were delineated so that the area of the basin at the farthest downstream pixel modeled was within the size range for which the models were developed $-0.01-103 \mathrm{~km}^{2}$ for the probability model and $0.01-27.9 \mathrm{~km}^{2}$ for the volume model (Cannon and others, 2010). The drainage basin sizes were kept at a minimum to improve model estimate accuracy, primarily for volume estimates (Dennis Staley and Jason Kean, U.S. Geological Survey, oral commun., 2013). Drainage basins with a total area exceeding the range of the probability and volume models were subdivided into smaller upstream and side tributaries.

Debris-flow hazards from a given basin also can be represented by a combined relative debrisflow hazard ranking that is based on a combination of both probability of occurrence and volume (Cannon and others, 2010). For this assessment, the estimated values of debris-flow probability and volume were categorized into five ranked classes, and these classes were added together, divided by two, and rounded up to maintain five integer classes to calculate the combined probability and volume 
relative hazard ranking, one for each storm (recurrence) event (table 1, pls. 3, 6, and 9). The probability classes were based on the range of probability values as, $0-0.15=1 ;>0.15-0.30=2 ;>0.30-0.45=3,>$ $0.45-0.60=4$; and $>0.60=5$ (pls. 1, 4, and 7). Volume estimates were classified as $0-5,000 \mathrm{~m}^{3}=1 ;>$ $5,000-10,000 \mathrm{~m}^{3}=2 ;>10,000-25,000 \mathrm{~m}^{3}=3 ;>25,000-100,000 \mathrm{~m}^{3}=4$; and $>100,000 \mathrm{~m}^{3}=5$. This combined ranking identifies a possible range of responses from drainage basins with the highest probabilities of producing debris flows with the largest volumes to drainage basins with the lowest probabilities of producing debris flows with the smallest volumes (Cannon and others, 2010). For example, the most hazardous drainage basins will have both the highest probabilities of occurrence and the largest estimated volumes of material. Slightly less hazardous rankings would occur in drainage basins modeled with a combination of either low probabilities and larger volume estimates or high probabilities and smaller volume estimates.

\section{Model Application}

Debris-flow probabilities and volumes were calculated along the drainage networks for the Beaver Creek Fire burn area by using the two empirical models. Within the area analyzed, 130 drainage basins were delineated and labeled by the watershed they occur in and numbered in downstream order (pls. 1-9, table 1). Not all small size drainage basins were delineated and numbered, but were included in the stream segment analysis. Probability, volume, or hazard ranking for the 130 numbered drainage basins only represents the value at the basin outlet. Within the drainage basins, probability and/or hazard rankings may be higher or lower and volume rankings may be smaller, as indicated by the stream segment analysis.

There are four types of independent variables necessary for evaluation of the probability and volume equations:

1. Topographic variables: The slope variables (\%SG30, eq. 2 and $S G 30$, eq. 3 ) along with the ruggedness ( $R$, eq. 2 ) were all derived from the $1 / 3$-arc-second DEM (Gesch and others, 2002; Gesch, 2007) using standard GIS processing techniques;

2. Soil variables: Two soil variables are used in the probability equations. Both the percent clay and liquid limit of the soil was obtained from the State Soil Geographic (STATSGO) database (Schwartz and Alexander, 1995; U.S. Department of Agriculture, Natural Resources Conservation Service, 2013);

3. Burn area variables: The final burn severity dataset was obtained in the form of a shapefile from the Forest Service Beaver Creek Fire Burned Area Emergency Response (BAER) team. Polygons within this dataset with a SEVERITY attribute of "High" or "Moderate" were selected to produce the mask of areas burned at moderate to high severity. This mask was used to create the required burn variables ( $\% A B$, eq. 2 and $A B$, eq. 3 );

4. Precipitation variables: Cannon and others (2008) found that most debris flows occur in response to storms with short recurrence intervals (from 2 to 10 years). Precipitation data were obtained from the National Weather Service (Corey Loveland, written commun., 2013) based on historical storm data for two weather stations near the burn area. To characterize the effects of rainfall conditions, the probability that a drainage basin could produce debris flows and the volume of a possible debris flow at the basin outlet were estimated for three storms:

1. A 2-year-recurrence, 1 -hour duration rainfall of $13 \mathrm{~mm}(0.51 \mathrm{in}$.), referred to as a 2 -year storm (a 50-percent chance of occurrence in any given year); 
2. A 10-year-recurrence, 1 -hour-duration rainfall of $19 \mathrm{~mm}(0.74 \mathrm{in}$.), referred to as a 10 -year storm (a 10-percent chance of occurrence in any given year);

3. A 25 -year-recurrence, 1-hour-duration rainfall of $22 \mathrm{~mm}(0.86 \mathrm{in}$.), referred to as a 25 -year storm (a 4-percent chance of occurrence in any given year).

Once the surfaces of the independent variables were developed, the probability and volume equations were solved using map algebra for each grid cell along the drainage network, thus deriving the probability and volume surfaces.

\section{Debris-Flow Model Estimates}

The hazards of debris flows from 130 drainage basins burned by the Beaver Creek Fire were assessed by estimating the probability of occurrence of a debris flow, estimating the volume of potential debris flows, and by combining the probability and volume estimates into a relative hazard ranking to assess the overall hazard for basins and stream segments.

\section{Debris-Flow Probability Estimates}

In response to the 2-year-recurrence storm model, the probability of debris-flow occurrence was greater than 60 percent at only one basin (WC 14 in the Willow Creek watershed) (pl. 1 and table 1). The 2-year-recurrence storm model indicated that along with basin WC 14, the probability of occurrence was 50 to 60 percent for seven other basins. Four of these basins are in the Deer Creek watershed (DC 15, DC 31, DC 32, and DC 33), one basin in the Greenhorn Creek watershed (GC 10), and two basins in the Willow Creek watershed (WC 20 and WC 21). All basins increase their probability of debris-flow occurrence with increased storm intensity or a lower recurrence interval storm event. In response to the 10-year-recurrence storm, the probability of occurrence was greater than 60 percent for seven basins. Three of these basins are in the Deer Creek watershed (DC 31, DC 32, and DC 33), one basin in Greenhorn Creek watershed (GC 10), and three basins in Willow Creek watershed (WC 14, WC 20 and WC 21). The probability of occurrence ranged from 50 to 60 percent for nine basins. Four of these basins are in the Deer Creek watershed (DC 15, DC 21, DC 34, and DC 36), one basin in Warm Springs Creek watershed (WS 17), and four basins in Willow Creek watershed (WC 3, WC 6, WC 10, and WC 19). In response to the 25-year-recurrence storm model, the probability of occurrence increased for all of the previously noted basins with basin WC 14 at a high of 78 percent. The probability of occurrence was greater than 60 percent for eleven basins. Five of these basins are in the Deer Creek watershed (DC 15, DC 31, DC 32, DC 33, and DC 36), one in the Greenhorn watershed (GC 10), one in the Warm Springs Creek watershed (WS 17), and four in the Willow Creek watershed (WC 14, WC 19, WC 20, and WC 21). The number of basins with a probability of occurrence of 50 to 60 percent increased to 12 . This 25 -year-recurrence storm event results in the first two basins in the Democrat Gulch subwatershed to have probability occurrences of 50 to 60 percent (DG 1 and DG 2). There are four basins in Deer Creek watershed (DC 21, DC 22, DC 34, and DC 38) with probabilities of 50 to 60 percent, one basin in Greenhorn Creek watershed (GC 7), one basin in Warm Springs Creek watershed (WS 9), and four basins in Willow Creek watershed (WC 3, WC 6, WC 10, and WC 17). Basins in the Baker Creek and Croy Creek watersheds (excluding the Democrat Gulch subwatershed) and basins draining to the Big Wood River do not have probabilities greater than 50 percent for the three modeled storm events (two are close at 45 and 46 percent probability of occurrence, basins BC 7 and BW 3, respectively). 
Stream segment analysis identifies stream segments within a basin with a higher or lower probability of debris-flow occurrence than estimated at the basin outlet. This is particularly important for basins with a low probability of debris-flow occurrence at the basin outlet but have stream segments in other parts of the basin with a high probability. For the 2-year-recurrence storm, five basins have stream segments with high probability in parts of the basin and a lower probability at the basin outlet (pl. 1). These basins with high probability stream segments are in the Deer Creek watershed (basin DC 31), the Willow Creek watershed (basins WC 3, WC 12, and WC 18), and the Warm Springs Creek watershed (basin WS 17). For the 10-year-recurrence storm model, 20 basins have stream segments with a high probability in parts of the basin and a lower probability at the basin outlet (pl. 4). These basins with high probability stream segments are in the Baker Creek watershed (basins BC 7 and BC 9), Deer Creek watershed (basins DC 7, DC 13, DC 16, DC 21, DC 22, DC 30, and DC 40), Greenhorn Creek watershed (basin GC 1), Warm Springs Creek watershed (basins WS 4 and WS 15), and the Willow Creek watershed (basins WC 1, WC 2, WC 3, WC 6, WC 12, WC 16, WC 17, and WC 18). For the 25 year-recurrence storm model, some of the previously noted basins for the 10-year-recurrence storm model plus several additional basins have stream segments with a high probability, such as BC 1, BW 6 , DC 9, DC 10, DC 17, DC 25, DC 29, DC 38, DC 41, DG 2, GC 7, WC 9, and WC 10 (pl. 7). All of the above listed basins are areas where a debris flow might occur within a portion of a basin but not necessarily at the outlet. This exemplifies the importance of stream segment analysis over simple basin outlet analysis.

\section{Debris-Flow Volume Estimates}

The debris-flow volumes estimated in this assessment are independent of the estimated debrisflow probabilities. As a result, drainage basins with high estimated debris-flow probabilities represent varying degrees of hazard to areas downstream, depending on the estimated volume of material mobilized in a debris flow. Estimated debris-flow volumes can vary by stream segment, as indicated by changes in stream segment color along a drainage network (pls. 2, 5, and 8). The stream segment analysis estimates the volume of debris-flow material mobilized above a given analysis point but does not account for potential within-basin deposition of mobilized material. Estimated debris-flow volumes ranged from a minimal debris-flow volume of $10 \mathrm{~m}^{3}$ to greater than $100,000 \mathrm{~m}^{3}$ for the three storm models (table 1). Estimated debris-flow volumes were greater than $100,000 \mathrm{~m}^{3}$ only in the 10- and 25 year-recurrence storm models. For the 25-year storm model, four three basins were greater than 100,000 $\mathrm{m}^{3}$ - one in the Baker Creek watershed (basin BC 1), one in the Warm Springs Creek watershed (basin WS 16), and two in the Willow Creek watershed (basins WC 12 and WC 18). Estimated debris-flow volumes ranged from $50,000 \mathrm{~m}^{3}$ to $100,000 \mathrm{~m}^{3}$ in 10 basins - Baker Creek watershed (basin BC 9), Deer Creek watershed (basins DC 10, DC 25, and DC 30), Greenhorn Creek watershed (basin GC 1), and Warm Springs Creek watershed (basins WS 1, WS 4, WS 10, WS 11, and WS 15) (table 1, pls. 5 and 8).

Unlike the debris-flow probability estimates for individual stream segments, which can increase or decrease within a basin, the debris-flow volume estimates only increase in a downstream direction. There are no instances of stream segment volume estimates which are greater than those estimated for the corresponding basin outlet. The stream segment debris-flow volume estimates continue to increase beyond the basin outlets; however, these estimates start to lose their validity as the basin size contributing to that stream segment increases beyond that which the debris-flow volume equation was derived from. 


\section{Debris-Flow Hazard Ranking}

The debris-flow hazard rankings were designed to combine the probability and volume models and help identify areas with both a high probability of debris-flow occurrence and a high debris-flow volume estimate. The hazard rankings of post-fire debris flows were produced by ranking and summing the probability and volume estimates as previously described. The debris-flow hazard rankings for all three storm models did not result in the highest hazard ranking of 5, indicating that none of the basins had a high probability of debris-flow occurrence and a high debris-flow volume estimate. The 2-yearrecurrence storm model produced no hazard rankings of 4; however, the hazard ranking was 4 for one basin in the Willow Creek watershed (WC 18), using the 10-year-recurrence storm model, and for three basins using the 25-year-recurrence storm model - two basins in the Willow Creek watershed (basins WC 12 and WC 18) and one basin in the Deer Creek watershed (basin DC 36) (table 1, pls. 3, 6, and 9). The hazard ranking of 4 for the basins in the Willow Creek watershed is due to high debris-flow volume estimates and mid-range probability estimates; the hazard ranking of 4 for the basins in the Deer Creek watershed is due to high probability estimates and mid-range debris-flow volume estimates (pl. 9).

Hazard rankings are elevated (greater than 2) for most of Baker Creek watershed ; however, the hazard ranking is elevated for only the Thompson Creek drainage (WS 16) in the Warm Springs watershed. Most of the Willow Creek and Deer Creek watersheds have elevated hazard rankings except for the headwaters areas. Hazard rankings are elevated in the entire southern half of Greenhorn Creek watershed. The Croy Creek watershed and the Democrat Gulch subwatershed have mixed elevated rankings (pls. 3, 6, and 9).

Stream segment analysis is similar to that of the debris-flow volume estimate stream segment analysis. Most of the hazard ranking stream segments increase in a downstream direction and match the basin outlet. There are only a couple instances to the contrary whereby the stream segment hazard ranking decreases within a basin.

\section{Use and Limitations of the Assessments}

This assessment provides estimates of debris-flow probability, volume, and combined relative hazard ranking in response to 1-hour-duration storms with 2-, 10-, and 25-year-recurrence intervals for the Beaver Creek Fire burn area. The estimates are based on predictive models developed with data from burned areas throughout the Western United States. Larger, less-frequent storms are more likely to produce much larger debris flows. Because individual storms may not affect the entire area at any given time, debris flows may not be produced from all basins during storms.

The debris-flow estimates are based on initial post-fire conditions and does not account for potential mitigating effects of post fire treatments. The analysis does serve to highlight, especially by the stream segment analysis, those parts of a basin with an increased debris-flow hazard ranking based on physical characteristics. The assessment given herein is estimated to be applicable for 2-3 years after the fire, depending on precipitation distribution (Cannon and others, 2010). 
The maps in this report may be used to prioritize areas where emergency erosion mitigation or other protective measures may be needed prior to rainstorms within these drainage basins, their outlets, or areas downstream of these drainage basins within the 2- to 3-year period of vulnerability following the Beaver Creek Fire. This assessment evaluates only post-fire debris flows and does not consider hazards associated with flash floods; such hazards may remain for many years after a fire.

This work is preliminary and is subject to revision and is being provided because of the need for timely "best science" information. The assessment is provided on the condition that neither the U.S. Geological Survey nor the United States Government may be held liable for any damages resulting from the authorized or unauthorized use of the assessment.

\section{Summary and Conclusions}

This assessment characterizes the post-fire debris-flow hazards that may exist within and downstream of the 2013 Beaver Creek fire near Hailey, Idaho. Geospatial data related to topography, burn severity, soil properties, and storm intensity was used to estimate the probability and volume of debris flows that may occur in response to a 2-year, 10-year, and 25-year recurrence interval rainstorm as well as a combined relative hazard ranking.

The probability of debris flow occurrence is highest in the eastern part of the Willow Creek watershed, the southern part of the Greenhorn Creek watershed, most of the Deer Creek watershed, the Democrat Gulch subwatershed and a couple drainages in the Baker Creek watershed. Probabilities of debris flow occurrence were low for most of the Warm Springs Creek watershed except for a basin in the Thompson Creek subwatershed. The probability of debris-flow occurrence increased with each increase in storm intensity with the highest probability at 78 percent for a basin in Willow Creek watershed. It is important to consider the stream segment probabilities as well because the basin probability value is derived from the basin outlet. Many basins have lower or more importantly higher probability values for stream segments within a basin compared to the outlet. These are areas within a basin where a debris flow might occur even though not likely at the outlet. Like the probability of debris-flow occurrence, the volume estimates increase with the increase in storm intensity, however, at a reduced rate. Estimates of debris-flow volume were highest in two basins in the Willow Creek watershed, the headwaters basin in the Baker Creek watershed, and the Thompson Creek subwatershed in the Warm Springs Creek watershed. These basins are not coincident with the high probability basins. Unlike the probability stream segment analysis, the volume estimates for stream segments does not vary much within a basin. The volume estimates tend to increase in a downstream direction.

Because many of the high probability and volume basins do not overlap, there are no combined hazard rankings with a high value of 5. Hazard rankings primarily are elevated in the eastern part of the Willow Creek watershed, the downstream part of the Deer Creek watershed, a couple basins in the Baker Creek watershed, and the Thompson Creek subwatershed within the Warm Springs Creek watershed. These areas indicate a significant possibility of debris-flow impact to homes, buildings, roads, bridges, and culverts that may be located both within and downstream of these basins. 


\section{References Cited}

Cannon, S.H., and Gartner, J.E., 2005, Wildfire-related debris flow from a hazards perspective, chap. 15 in Jakob, Matthias, and Hungr, Oldrich, eds., Debris-flow hazards and related phenomena: Chichester, U.K., Springer-Praxis Books in Geophysical Sciences, p. 321-344.

Cannon, S.H., Gartner, J.E., and Michael, J.A., 2007, Methods for the emergency assessment of debrisflow hazards from basins burned by the fires of 2007, southern California: U.S. Geological Survey Open-File Report 2007-1384, 10 p., http://pubs.usgs.gov/of/2007/1384/.

Cannon, S.H., Gartner, J.E., Rupert, M.G., Michael, J.A., Rea, A.H., and Parrett, C., 2010, Predicting the probability and volume of postwildfire debris flows in the intermountain western United States: Geological Society of America Bulletin, v. 122, p. 127-144.

Cannon, S.H., Gartner, J.E., Wilson, R.C., and Laber, J.L., 2008, Storm rainfall conditions for floods and debris flows from recently burned areas in southwestern Colorado and southern California: Geomorphology, v. 96, p. 250-269.

Das, B.M., 1983, Advanced soil mechanics: New York, McGraw-Hill, 511 p.

DeBano, L.F., 1981, Water repellant soil-A state-of-the-art: Berkeley, Calif., U.S. Department of Agriculture, Forest Service, Pacific Southwest Forest and Range Experiment Station, General Technical Report PSW-46, 21 p.

DeGraff, J.V., Wagner, D.L., Gallegos, A.J., DeRose, M.B., Shannon, Casey, and Ellsworth, Todd, 2011, The remarkable occurrence of large rainfall-induced debris flows at two different locations on July 12, 2008, Sierra Nevada, California: Landslides, v. 8, no. 2, p. 343-353.

Doerr, S.H., Shakesby, R.A., and Walsh, R.P.D., 2000, Soil water repellency-Its causes, characteristics and hydro-geomorphological significance: Earth-Science Reviews, v. 15, p. 33-65.

Environmental Systems Research Institute, Inc., 2013, ArcGIS v. 10.1: Redlands, Calif., ESRI.

Gesch, D.B., 2007, The National Elevation Dataset, in Maune, D., ed., Digital Elevation Model Technologies and Applications: The DEM Users Manual, 2nd Edition: Bethesda, Maryland, American Society for Photogrammetry and Remote Sensing, p. 99-118.

Gesch, D., Oimoen, M., Greenlee, S., Nelson, C., Steuck, M., and Tyler, D., 2002, The National Elevation Dataset: Photogrammetric Engineering and Remote Sensing, v. 68, no. 1, p. 5-11.

Helsel, D.R., and Hirsch, R.M., 2002, Statistical methods in water resources: New York, N.Y., Elsevier Studies in Environmental Science, v. 49, 529 p.

Letey, John, 2001, Causes and consequences of fire-induced soil water repellency: Hydrological Processes, v. 15, p. 2867-2875.

Melton, M.A., 1965, The geomorphic and paleoclimate significance of alluvial deposits in southern Arizona: Journal of Geology, v. 73, p. 1-38.

Moody, J.A., and Martin, D.A., 2001a, Hydrologic and sedimentologic response of two burned watersheds in Colorado: U.S. Geological Survey Water-Resources Investigations Report 01-4122, 138 p., http://pubs.usgs.gov/wri/2001/4122/report.pdf.

Moody, J.A., and Martin, D.A., 2001b, Initial hydrologic and geomorphic response following a wildfire in the Colorado Front Range: Earth Surface Processes and Landforms, v. 26, p. 1049-1070.

Rivix, LLC, 2012, RiverTools 3.0.3: Broomfield, Colo., Rivix, LLC, accessed July 2012, at http://rivix.com.

Romkens, M.J.M., Prasad, S.N., and Whisler, F.D., 1990, Surface sealing and infiltration, chap. 5 in Anderson, M.G., and Burt, T.P., eds., Process studies in hillslope hydrology: New York, John Wiley and Sons, p. 127-172. 
Ruddy, B.C., 2011, Probability and volume of potential postwildfire debris flows in the 2011 Horseshoe II burn area, southeastern Arizona: U.S. Geological Survey Open-File Report 2011-1197, 10 p., http://pubs.usgs.gov/of/2011/1197/.

Schwartz, G.E., and Alexander, R.B., 1995, Soils data for the conterminous United States derived from the NRCS State Soil Geographic (STATSGO) Database: U.S. Geological Survey Open-File Report 95-449, accessed September 2013, at http://water.usgs.gov/GIS/metadata/usgswrd/XML/ussoils.xml.

Staley, D.M., 2013, Emergency assessment of post-fire debris-flow hazards for the 2013 Rim Fire, Stanislaus National Forest and Yosemite National Park, California: U.S. Geological Survey Open-File Report 2013-1260, 11 p., 3 pls., http://pubs.usgs.gov/of/2013/1260/.

Staley, D.M., Gartner, J.E., Smoczyk, G.M., and Reeves, R.R., 2013a, Emergency assessment of postfire debris-flow hazards for the 2013 Mountain fire, southern California: U.S. Geological Survey Open-File Report 2013-1249, 13 p., 3 pls., http://pubs.usgs.gov/of/2013/1249/.

Staley, D.M., Smoczyk, G.M., and Reeves, R.R., 2013b, Emergency assessment of post-fire debris-flow hazards for the 2013 Powerhouse fire, southern California: U.S. Geological Survey Open-File Report 2013-1248, 13 p., 3 pls., http://pubs.usgs.gov/of/2013/1248/.

Tillery, A.C., and Matherne, A.M., 2013, Postwildfire debris-flow hazard assessment of the area burned by the 2012 Little Bear Fire, south-central New Mexico: U.S. Geological Survey Open-File Report 2013-1108, 15 p., 3 pls., http://pubs.usgs.gov/of/2013/1108/.

U.S. Department of Agriculture, Natural Resources Conservation Service, 2013, U.S. General Soil Map (STATSGO2): accessed September 30, 2013, at http://soildatamart.nrcs.usda.gov/.

Verdin, K.L., Dupree, J.A., and Elliott, J.G., 2012, Probability and volume of potential postwildfire debris flows in the 2012 High Park Burn Area near Fort Collins, Colorado: U.S. Geological Survey Open-File Report 2012-1148, 9 p., 2 pls., http://pubs.usgs.gov/of/2012/1148/.

Verdin, K.L., Dupree, J.A, and Stevens, M.R., Postwildfire debris-flow hazard assessment of the area burned by the 2013 West Fork Fire Complex, southwestern Colorado: U.S. Geological Survey OpenFile Report 2013-1259, 30 p., 3 ps., http://pubs.usgs.gov/of/2013/1259.

Verdin, K.L., and Greenlee, S., 2003, Continuous parameterization using EDNA, in 2003 ESRI User's Conference, San Diego, Calif., July 7-11, 2003, Proceedings: Redlands, Calif., ESRI, accessed June, 2012, at http://gis.esri.com/library/userconf/proc03/p0617.pdf.

Verdin, K.L., and Worstell, B., 2008, A fully distributed implementation of mean annual streamflow regional regression equations: Journal of the American Water Resources Association, v. 44, p. 15371547, doi: 10.1111/j.1752-1688.2008.00258.x

Wells, H.G., 1987, The effects of fire on the generation of debris flows in southern California, in Costa, J.E., and Wieczorek, G.F., eds., Debris flows/avalanches_-Process, recognition, and mitigation: Geological Society of America, Reviews in Engineering Geology, v. 7, p. 105-114.

Woods, S.W., Birkas, Anna., and Ahl, R.S., 2006, Spatial variability of soil hydrophobicity after wildfires in Montana and Colorado: Geomorphology, v. 86, p. 465-479. 
Publishing support provided by the U.S. Geological Survey Publishing Network, Tacoma Publishing Service Center

For more information concerning the research in this report, contact the Director, Idaho Water Science Center

U.S. Geological Survey

230 Collins Road

Boise, Idaho 83702

http://id.water.usgs.gov

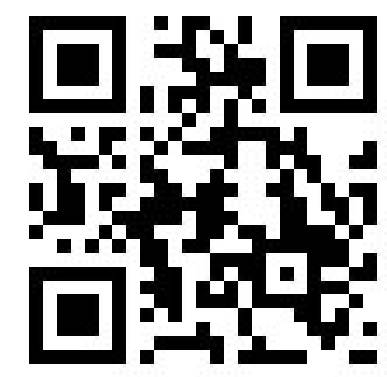




\section{ख़}

